\title{
CD REVIEWS
}

JOHN TAVENER: The Veil of the Temple. Choir of the Temple Church, Holst Singers, Patricia Rozaro (sop) c. Stephen Layton. RCA 82876661542.

TAVENER: Lament for Jerusalem. Patricia Rozario (sop), Christopher Joey (counter-ten), Sydney Philharmonic Chorus, Australian Youth Orchestra c. Thomas Woods. ABC Classics 476 160-5.

TAVENER: Birthday Sleep; Butterfly Dreams; The Second Coming; Schuon Hymen; As one who has slept; The Bridal Chamber; Exhortation and Kohima; Shunya. Polyphony c. Stephen Layton. Hyperion CDA67475.

The world première in June 2003 of Sir John Tavener's seven-hour all-night vigil The Veil of the Temple provided one of the most memorable and powerful musical experiences of recent years. For the composer, it marked the culmination of a gradual turning away from Orthodox religion towards a broader approach to religious beliefs. This new-found ecumenism has inspired a series of large-scale choral pieces, which communicate a palpable sense of joy and radiance, as well as expanding Tavener's orchestral palette to include such instruments as the powwow drum and Tibetan temple bowl.

RCA's release of The Veil of the Temple is a concert-length version, first heard at the 2004 Proms. Accommodated on two CDs and lasting just two hours, the recording is taken from the memorable first performances, whose unique atmosphere and magical sense of theatre and ritual is faithfully captured on the discs. Without the visual splendour of the 800-year-old Temple Church, the candles and the incense, inevitably the scale and sheer audacity of the original enterprise is diminished, but there are plenty of breathtakingly beautiful and spiritually intense moments here - notably the four sublime sections Tavener is now transcribing into Anthems and the hauntingly memorable version of The Jesus Prayer which recurs throughout, acting, as the composer puts it - as the 'heartbeat' of the work. The choral contributions, under the expert and inspiring guidance of Stephen Layton, are both assured and fervent. Even listeners implacably unconvinced by Tavener's music should seek out this remarkable piece. I hope some enterprising record company will one day have the courage and vision to release a full version with these artists, preferably also on DVD in the Temple Church, whose physical spaces are built into the very fabric of the score.

Since the first performance of The Veil, Stephen Layton has continued to champion Tavener tirelessly, both in the concert hall and in the recording studio. A collection of choral works with Polyphony, recently released on the Hyperion label, is by far the most satisfying and artistically impressive of the many collections of Tavener's music. Thanks to a combination of idiomatic interpretations by artists who know and understand the composer's vision, and a natural and wide-ranging recording, the strength and integrity of Tavener's music shines through with persuasive conviction. The artlessly moving spiritual vistas opened up by the harmonic transformations of Birthday Sleep (1999) are developed further in Schuon Hymen (2003) and Shunya (2003), which inhabit the same ecstatic, primal sound-world as The Veil of the Temple. All the pieces on this immensely satisfying disc are interpreted with simple dedication.

Some of the works on the Hyperion CD were given by the same performers at the composer's lavish 60th birthday concert at the Barbican in November 2004. The world première of the evening was provided by Pratrirupa (a Sanskrit word meaning 'reflection') performed by the English Chamber Orchestra with Ralf Gothoni as conductor/soloist. This 45-minute piece for piano and strings was not a 'concerto', but rather a series of contrasting sections growing organically at each repetition, in which the two musical forces mirrored each other. The main material consisted of a dignified Hindu dirge-like theme of delicate beauty and a manically jazzy piano figure initially clenched at either extreme of the keyboard, which then proceeded via chromatic chords in contrary motion to meet in the middle. It is not Tavener's custom to develop his material in the conventionally Western sense, but rather to build up an accumulation of details, increasing in intensity. Whereas this procedure was successful with a piece on the scale of The Veil, it seemed less convincing in this shorter structure. This felt like one of Tavener's less compelling recent creations; perhaps conventional musical forces are no longer really suited to his devotional utterances. 
The concert also featured the London première of Supernatural Songs (2002), settings of W.B. Yeats for mezzo-soprano, strings, powwow drum and Hindu temple bowl. Sarah Connolly, replacing an indisposed Susan Graham at short notice, brought a ravishing tone and sure technique, fully deserving the fulsome applause she received. The songs constitute one of the composer's finest achievements: the glorious, soaring violin theme arched over sonorous, cosmic bass-instrument chord-changes in his setting of $O$ Do Not Love Too Long displayed something of John Barry's melodic gift, while the concluding, ravishingly tender meditation on death, Where there is nothing (there is God) was inspired: this was music which truly sounded 'from the other side' in its primordial simplicity. Stephen Layton conducted with great empathy and passion.

Two Mystical Love Songs by Tavener, both lasting around 50 minutes, stand out among his post-Veil compositions. Lament for Jerusalem, recently released on the $\mathrm{ABC}$ Classics disc listed above, uses both Christian and Islamic texts. It has a formal simplicity sustained by a hypnotically measured pace and a pure musical language which ranges from the ecstatic in the choruses to the sublime in Patricia Rozario's contributions, which achieve a Mozartian grace and innocence. Something of the sublime transcendence of The Veil touches Tavener's Lament, but, as befits a love song, it is a much more intimate and personal statement.

The Radio 3 broadcast of the world première of Tavener's Hymn of Dawn, with Stephen Layton conducting the Ulster Orchestra, ${ }^{1}$ revealed it to have strong links with The Veil, both in the exotic orchestration and in the actual musical material. The use of flute and violin as well as soloists adds variety of expression and the work has much more rhythmic and well as melodic interest than Lament. It is more adventurous in its texts, too, using Hindu, Sufi, Christian and Jewish sources. I hope this substantial and rewarding work will also appear on disc soon, preferably with the same forces under Stephen Layton, whose dedication to the score shone through every bar of this remarkably assured first performance.

Sir John Tavener is one of the most popular and oft-recorded contemporary composers, yet also one of the most controversial. His spiritual quest for simplicity and serenity has often been met with critical derision and accusations of 'dumbing down'. His sheer prolificacy has occasionally aroused suspicions of a lack of

\footnotetext{
${ }^{1} 29$ January this year, in 'Hear and Now' (BBC Radio 3).
}

quality control in his creative outpourings. Yet The Veil of the Temple is a masterpiece by any standards, a magnum opus which sums up Tavener's life's work in a glorious, allencompassing manner. His most recent works possess an artless divinity. However, they are extremely difficult to bring off: the supreme simplicity of the language and the ritual-like repetition can, if not directed with absolute conviction, lead easily to banality and stultification. Fortunately, with a musician of the calibre of Stephen Layton at the helm, nothing is presented half-heartedly; every bar is considered and placed within the context of the whole. The legacy of one of Britain's most distinctive and communicative contemporary composers is already in safe hands.

Paul Conway

JOAN GUINJOAN: Concerto for clarinet and orchestra; Concerto for piano and orchestra; Música per a violoncel $i$ orquestra. Joan Enric Lluna (cl), David Abramovitz (pno), Lluís Claret (vlc). Orquestra Simfònica de Barcelona i Nacional de Catalunya, c. Ernest Martínez Izquierdo. Harmonia Mundi HMI 987056.

Three works for soloist and orchestra from Joan Guinjoan (born 1934), spanning the composer's 30-year creative maturity. ${ }^{2}$ Serious engagements with the problems/pleasures of large-scale singlemovement form and of mediation between individual and collective, receiving highly competent, committed readings from the protagonists, deftly accompanied by the OBC under their young musical director. ${ }^{3}$

Similarities and differences between the works are fascinating. All have the same basic groundplan (action-reflection-varied reprise-peroration) and testify to Guinjoan's long-term love-affair with the minor third, as well as sharing specific elements fundamental to his musical iconography; yet their manners and ethos are entirely different.

\footnotetext{
2 For more information on this Catalan composer, see my article in Tempo Volume 59 No. 232 (April 2005), pp.14-22. There are at present - four other concertos in Guinjoan's catalogue: for piano and chamber orchestra (1963, his graduation piece from Schola Cantorum, Paris), for violin (1986), for bassoon with instrumental octet (1989; there is a version for saxophone by Manuel Miján) and for guitar (1990). The latter two are available on CD. A percussion concerto (for Tristan Fry) is in incubation.

3 This release has won the 2004 CD Compact magazine Best Recording, Spanish Contemporary Music, award (analogous to the Gramophone Awards in the UK).
} 
Música per a violoncel i orquestra (1975, revised 1980) and the Clarinet Concerto (2004) both last around 20 minutes and are kicked off by unaccompanied soloist. In the earlier work, the cello is subjected to a five-and-a-half minute interrogation which throws up a range of textural, motivic and tone-colour resources. Some of these are pulled into a tight ostinato, whereupon the orchestra wakes up. Negotiations and accommodations between soloist and orchestra spin the latent material into longer, balanced phrases, the cello gradually spiralling to its highest range. A flurry of colouristic display disperses the accumulated tension and the music dissolves, suspended and circling, into eerily beautiful night sounds, tightly constructed but exquisitely intangible. Material from the opening cadenza is then reworked in the afterglow of the previous section, and in an agitato coda the cello skirmishes with the orchestral choirs by turns.

The Clarinet Concerto opens to the soloist reflecting on a handful of pitches, dialoguing between its registers and dynamic levels. A sequential riff conjures the orchestra (which muses on a four-note refrain in the bass), with which the soloist, flitting and swooping, swaps short phrases until the orchestra commandeers the opening material, establishing grounds for more involved debate. The work unfolds with wit and grace rather than drama, but the uncluttered textures and relaxed, improvisatory solo writing belie the rigour of this impeccably crafted score made from supple bass lines, malleable motives, translucent harmony and unforced counterpoint. The structural repeat is transposed, varied and redistributed, and an agile coda has the soloist in cahoots with its orchestral counterparts.

Weighing in at 26 minutes plus, the Piano Concerto (1983) is a muscular, incisive affair, partly because the orchestra, confronted and provoked by the soloist, is not obliged to fight with one arm behind its back. The piece is the apotheosis of Guinjoan's orchestral technique and piano writing at the time of composition. Introductory rumbling evolving into brilliant display, the soloist's hurled staccato chords become the ritornello in a hybrid of rondo and variations, complete with solo episodes developed contrapuntally. The second main section - libero - investigates Guinjoan's pianistic lexicon in dreamlike suspension, a dissertation on a symmetrical diatonic figure (G F\# D E C B) which is taken up by the orchestra before being transformed into fleet arabesques. The recapitulation - chopped, changed and reinvented with the benefit of hindsight - is rounded by a four-minute cadenza, and the perpetual-motion coda (shades of Chopin's B minor Sonata) finally collapses to the darkness of the opening, and despite a defiant rally by the soloist - the work escapes only in the last bar from Bergian attenuation.

Programme, performance and engineering combine to make this $\mathrm{CD}$ an excellent introduction to Guinjoan's art and - for all you soloists out there - a pressing invitation to get off the beaten track.

Benjamin K. Davies

ANTHONY GILBERT: On Beholding a Rainbow ${ }^{1,4}$; Certain Lights Reflecting ${ }^{2,4}$;... Into the Gyre of a Madder Dance $^{3}$; Unrise ${ }^{3} .{ }^{1}$ Anthony Marwood (vln), ${ }^{2}$ Susan Bickley (mezzo), ${ }^{3}$ RNCM Wind Ensemble c. Clark Rundell, ${ }^{4}$ RNCM Symphony Orchestra c. Garry Walker. NMCD105.

The word nascondita ('hidden') occurs twice in this new release of music by Anthony Gilbert: as a 'hidden' fugue in the third movement of the orchestral song-cycle Certain Lights Reflecting (1988-9) and, more overtly, as part of the title of the first movement of his violin concerto, On Beholding a Rainbow (1992-7). This is not, perhaps, entirely inappropriate, as for many years it has been possible to think of Gilbert's many talents as being somewhat hidden, mainly due to a relative sparsity of performances. Recently, however, with the dual celebrations of his seventieth birthday last year in London and Manchester, things seem to have changed and the composer himself has spoken of experiencing something of an 'Indian summer'.

This CD features four of Anthony Gilbert's strongest and most persuasive works: ... Into the Gyre of a Madder Dance (1994) and Unrise (2001) for wind ensemble, plus the already referred-to orchestral pieces. The wind and brass music is both deftly and pungently handled and receives committed performances from the RNCM Wind Ensemble under Clark Rundell's baton, as does the violin concerto with Garry Walker steering Anthony Marwood and the RNCM Symphony Orchestra through this lyrical and ravishing work with highly impressive interpretations. Indeed, the sheer professionalism of the student performances (in name only) come close to that of the BBC Symphony Orchestra under Sir Andrew Davis in the song-cycle.

In common with Certain Lights Reflecting, ... Into the Gyre of a Madder Dance derives its title from the Lancashire-born Tasmanian poet, Sarah Day, and celebrates the various cyclic rotations found 
in the natural world. Scored for triple woodwind, four horns and two trumpets, the piece juxtaposes, then gradually reconciles, two contrasting ideas and textures. Clear and logical in its harmonies, ...Into the Gyre... packs a great deal into its seven minutes, whilst nodding affectionately to Stravinsky's ghost in passing. I have written on Unrise elsewhere (Tempo No.218, October 2001, p. 34) but wish to affirm this work's continuing power, which seems as fresh as it was at that summer's Spitalfields Festival .

Certain Lights Reflecting for mezzo-soprano (Susan Bickley, here) and orchestra sets five poems by Sarah Day to piquant and sensual effect. This recording captures the nuances of the vocal line, as well as the panoply of dazzling orchestral colours, in a manner that the first performance (Cheltenham, 1989) did not wholly achieve. As a result, everything emerges with vivid clarity and Gilbert's responses to Day's images are immediately evocative and telling - the string-led cantus in 'Two Wreaths' and the hubbub of cracked, whooshing quasi-fanfares in 'White Cockatoos', for example, are just two instances of his very precise and sophisticated aural imagination.

The climax of the CD is the performance of $O n$ Beholding a Rainbow, which increasingly appears to be Anthony Gilbert's orchestral masterpiece (see Tempo No.210, October 1999, p. 38). This intense, lyrical, almost Bergian concerto ingeniously makes play with notions of hybrid forms and their resultant ambiguity, rhythmic and durational cycles (micro/macro) and a vibrant as well as dramatic sense of local and long-range timbral awareness. On this listening, I felt the last movement to be darker than in the first (broadcast) performance; a hybrid of Scherzocum-Totentanz, perhaps?

It is difficult to think of a more timely or deserved release than this one, which presents us with some of the most positive, individual and elegant music to have been written during the past couple of decades. The harmonic integrities are self-evident, but there remain plenty of subtleties to further tempt and tease the un-jaded mind and ear.

Richard Leigh Harris

MAXWELL DAVIES: Naxos Quartets Nos. 3 and 4. Maggini Quartet. Naxos 8.557397.

Maxwell Davies's third quartet, as is well documented, was originally intended as an 'abstract' work exploring the potentials of various magic squares (some of which are applied to a plainsong); as such, it is not dissimilar in conception to the first two works in the cycle. However, the illegal invasion of Iraq that occurred during the composition of the third quartet left its traces in both the character and substance of the music. ${ }^{4}$ Nor was the fourth quartet unaffected by the conflict, for Davies started out by attempting to write a lighter, contrasting work to its predecessor, only to find that the same themes were to resurface. Considered as a pair, they take the Naxos cycle into unanticipated territories, and make for a fascinating, if at times uncomfortable, instalment in the project.

The start of the third Naxos Quartet does not immediately reveal Davies's outrage at the Iraq invasion. Indeed, compared to the expositions of the first two quartets, there are significantly fewer juxtapositions of contrasting material, with a corresponding emphasis on continuity, as well as a much more audible sense of harmonic direction. But as the movement progresses, the musical surface becomes increasingly distorted, culminating in a savage march that is rendered somewhat ridiculous by the use of complex cross rhythms. The way in which this evaporates into a beautiful 'slow meditation' is vintage Maxwell Davies: the juxtaposition of the absurd and the lyrical intensifies both.

The slow movement continues the protest by means of the avoidance, and then subsequent distortion of, the 'In Nomine' melody. Here too is a re-emergence of the scherzo material left in the 'stratosphere' at the end of the first quartet, part of Davies's original inception of connecting members of the cycle. However, the material is appreciably slower in the third quartet than in the first, almost as if in the interim it had been contaminated and weighed down by the external political situation. The third movement (a series of Inventions after Bach) expands this material, culminating in a nauseating 'hymn' in which the use of slow, wide vibrato serves to exaggerate the grotesquery.

As in the first three movements, the final fugue turns towards the end to contemplate Iraq, by means of allusions to the parodistic elements within the quartet as a whole. Thus although the quartet makes use of numerous traditional polyphonic genres (doubtless part of the original conception of the work), none of the 'abstract'

\footnotetext{
${ }^{4}$ For more on this, see Rodney Lister, 'Peter Maxwell Davies's "Naxos" Quartets', Tempo Vol. 59 No. 232, pp. 2-12.
} 
designs are allowed to run their course, to find closure on their own terms. The use of parody enables the external world to 'enter' and disrupt the otherwise 'purely musical' discourse. In reference to the quartet (and therefore Iraq) Davies has commented that it is just impossible to neither see, nor hear' what is happening; his music is a powerful artistic response from someone who both sees and hears what is happening around him.

The fourth Naxos Quartet is the first in the cycle to be cast in a single movement. Taking Brueghel's picture of children's games as inspiration, the work juxtaposes active episodes (representing the more exuberant children's games) with slower ones (quieter pursuits). An opening idea encompassing a progression from $\mathrm{F}$ to B encapsulates the overall tonal argument; transformations of this motion provide the warp and weft of the various sections. The intention is to provide, I assume, an underlying logic to the otherwise capricious ordering of ideas, although it is not always easy to follow. More immediate is the continued sense of vividly characterized episodes drawing us into new expressive areas.

In his programme note to the work, Davies notes that in thinking about children's games, he was unable to avoid the underlying adult motives of aggression and war, and their consequences. In this sense, the fourth quartet is not a lighter contrast to the third, but rather a companion piece exploring the same dark corners of the human condition.

The Magginis are persuasive and responsive interpreters of Davies's music; indeed, their recording of the first two quartets was shortlisted for a Classical Brits Award. The nomination may not reveal anything about the artistic significance of these works, but it nevertheless indicates the degree to which Davies's music is able to connect with a larger public than that of many of his peers. Part of this connexion is doubtless due to the availability of the music - the entrepreneurial marketing of Davies's work via his MaxOpus website is, to my knowledge, unprecedented in its scale. (Those who like their creative artists to be above such worldly concerns might well pause to consider how businessminded composers such as Haydn and Beethoven might have exploited such a resource, had it been an option for them.) But such an enterprise would not succeed if the music had nothing to say. Davies's continued commitment to producing works that, at their finest, address contemporary issues whilst communicating directly to the audience without compromising his musical values demands our full attention. Thus it is with the Naxos Quartets: they are rigorous, (for some) challenging, and immensely rewarding. Given the strong recorded performances, and the budget price that they have been released at, I have no hesitation in recommending them.

Edward Venn

PASCAL DUSAPIN: Perelà, uomo di fumo. Orchestre National de Montpellier c. Alain Altinoglu. Naïve MO 782168 (2-CD set).

DUSAPIN: 7 Études pour piano; À quia (piano concerto). Ian Pace (pno), Orchestre de Paris c. Christoph Eschenbach. Naïve MO 782164.

DUSAPIN: Granum Sinapis; Umbrae Mortis; Dona eis. Choeur de Chamber Accentus, Ensemble Ars Nova c. Laurence Equilbey. Naïve MO 782116.

DUSAPIN: String Quartets Nos. 1 and 4. Danel String Quartet. Accord 4761919.

DUSAPIN: String Quartets Nos. 2 'Time Zones' and 3. DUTILlEUX: Ainsi la Nuit. Arditti String Quartet. Naïve MO 782125.

Pascal Dusapin has developed over the last quarter of a century into one of the most distinctive composers in the contemporary musical arena. His wide-ranging catalogue encompasses practically every genre from solo pieces to large-scale operas. Four consummate string quartets crown an abundance of chamber works; there is some highly individual choral music, concertos demonstrating a keen understanding of the possibilities of their solo instrument and an ongoing series of inventively scored 'Solos for orchestra'. Opportunities to hear his large-scale pieces in the concert halls of the United Kingdom have been all too few in recent years. Fortunately, the Naïve label has released many of his major works and Accord have helpfully filled in other gaps in his discography, so it is possible to acquire on $\mathrm{CD}$ a representative selection of his inimitable contributions to all genres.

Whichever medium he is writing for, Dusapin deconstructs it thoroughly to reach the very essence of sounds implied by 'concerto' or 'quartet' or 'opera'. His major acknowledged influences are Varèse and Xenakis, whose seminars at the Sorbonne Dusapin attended for four years in the 1970s; yet his own sound-world is utterly distinctive, the result of scrupulous craftsmanship and ruthless self-criticism, every note compelled to justify its existence within the overall conception. 
An excellent starting point is a double-CD set containing performances of Dusapin's 7 Études for piano (1997-2001) and his Piano Concerto $\dot{A}$ quia (2002), both featuring the brilliant playing of Ian Pace, an inspired champion of the composer. Surprisingly, the Études are Dusapin's first largescale foray into writing music for the instrument. Lasting for just under an hour, they are rigorous and self-disciplined, founded upon plain gestures, characteristically laced with sadness and alternating between a sense of melancholic resignation and repressed rage at the music's inherent restrictions. The first Etude might almost be a 'Fantasia upon one note': the material rarely wanders from repeated fragments like a lone, wandering voice. By contrast the Fourth Étude begins in violent toccata-like spluttering, but is gradually stripped down to its own inner workings.

The Piano Concerto's title $\dot{A}$ quia refers to a French term meaning 'nonplussed'; the piece explores themes of non-communication and alienation as the two traditional protagonists of piano soloist and orchestra fail to connect or achieve dialogue. When they play together (and the orchestra is daringly silent for large stretches), in what one might call an anti-development section, they repeat each other's material in a futile attempt to make contact. Despite, or perhaps because of this, there are moments of real beauty and poignancy in this highly individual concerto, inspired by contemporary political events. Superb performances are complemented by a bonus DVD containing extensive footage of rehearsals, interspersed with illuminating interviews with Dusapin, as well as complete performances of Études 1 and 4 by Ian Pace, which makes this release an essential purchase.

Dusapin's four string quartets form part of a concept he terms the 'infinite quartet', in which each new example comments on its predecessor and presages the issues tackled by its successor. The First is an extensively revised early work, its enigmatic, epigrammatic nature the result of an enduring love of Samuel Beckett's writings. The Second, entitled Time Zones, is a much more substantial piece in 24 movements (one for each planetary time zone) which questions and deconstructs the inherited idea of the string quartet. By contrast, the Third is classically proportioned in four movements, while the fourth evolves with different voices splintering off from each other within a compact, eloquent one-

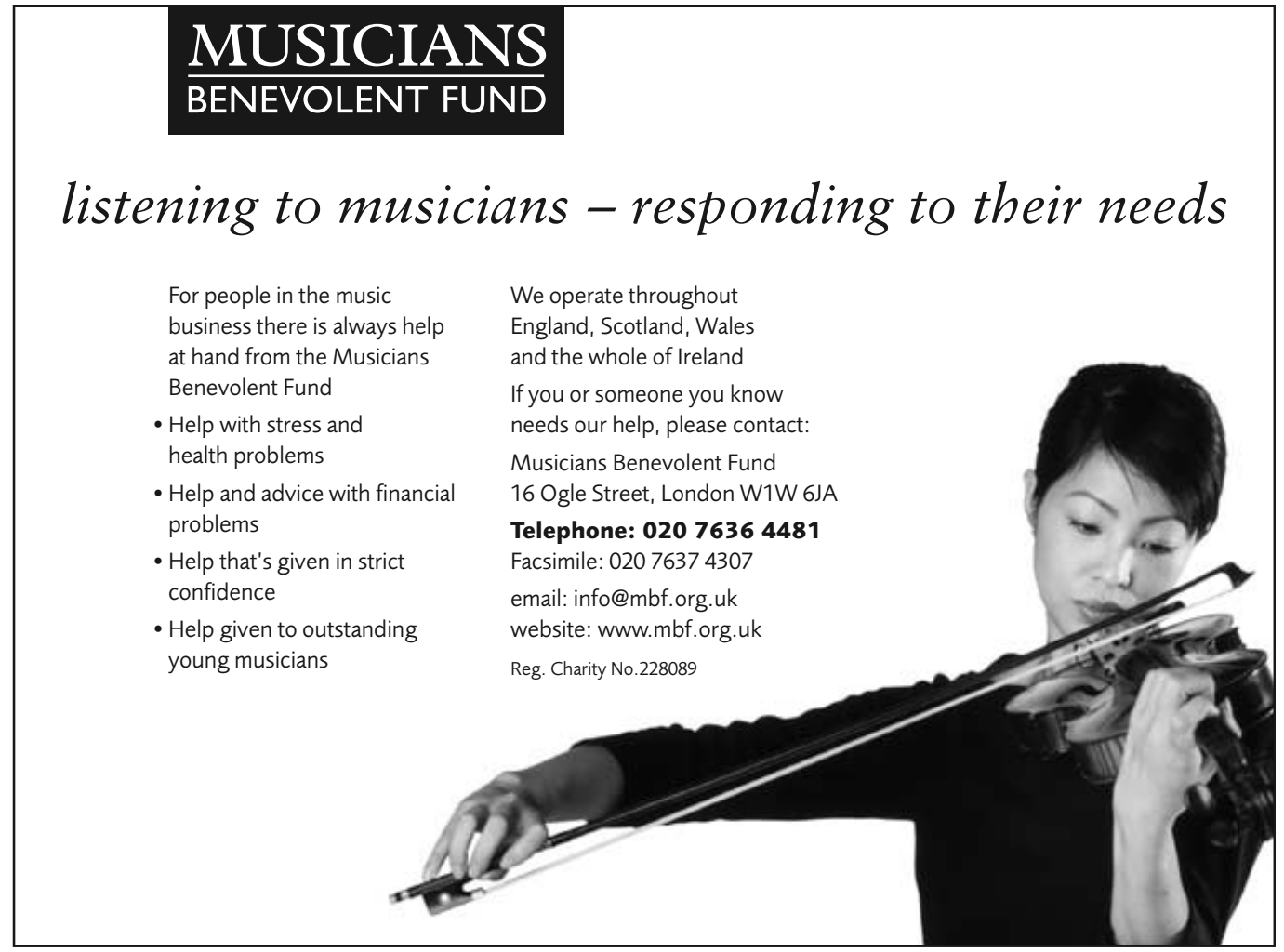


movement structure. Fortunately, the Accord and Naïve labels have released all four quartets between them - the Second and Third in the hands of the Arditti String Quartet and the First and Fourth by the Danel Quartet: both discs repay repeated listening, as Dusapin typically reinvents and challenges the genre with thought-provoking results.

Three major pieces for mixed choir, Granum Sinapis, Umbrae Mortis and Dona Eis, find the composer at his most inwardly contemplative. The first piece is a spiritual, meditation reminiscent of plainchant. Umbrae Mortis is a brief torso of a Mass for the Dead, whose brevity raises more questions than it answers. In Dona eis the choir is accompanied by the seven wind instruments (but minus the double bass), used by Varèse in his Octandre. Dusapin avails himself of myriad vocal devices, from sounds of breathing, to singing through a closed mouth, to the spoken voice. The Naïve disc containing these three works makes an ideal introduction to Dusapin's profoundly personal approach to the human voice.

Dusapin's four operas punctuate his output like sounding posts at regular intervals. His three early operas, Roméo et Juliette (1989), Medeamaterial (1992), and To Be Sung (1994) share an exploratory, scientific approach to the form, in the manner of Xenakis, but without the latter's overriding concern for drama. Dusapin's most recent opera, Perelà, uomo di fumo, is based on a novel by Aldo Palazzeschi and is sung in Italian. It is a variation on the story of Christ - Perelà, the mysterious 'man of smoke', is initially welcomed and adored because of his uniqueness, but eventually ill-treated, judged and condemned, returning back to his original state. Exploring the full range of operatic registers, the opera is divided into ten highly contrasted 'chapters'. The live recording recently released by Naïve has a tangible sense of atmosphere and theatre but occasionally obscures the fantastic detail in Dusapin's intricate instrumental writing. The musical resources employed are huge, involving piano, percussion, and onstage organ and wind band, making this Dusapin's largest-scale work to date and something of a summing-up, not only of his operatic output, but also of ten years' worth of concertante and instrumental works. In the title role, tenor John Graham-Hall brilliantly creates a genuine presence out of the most insubstantial and chameleon-like of characters. The well-filled accompanying booklet includes an interview with Dusapin, a revealing essay and, invaluably, a complete libretto.

Naïve's dedicated and extensive coverage, touching all forms of Dusapin's creative output, is a heartening example of a recording company placing their faith in a contemporary composer. There are some omissions, however, which Naïve will surely address in due course. Trio Rombach (1997), one of the most spellbindingly poetic chamber pieces of recent years, brought heartwarming depth and humanity to the BMIC Cutting Edge Tour of 2002, and is perhaps the strongest candidate for future CD release, while among his series of 'Solos for orchestra', the first (Go, 1992), the fourth (Clam, 1998) and the most recent (Exeo, 2002) all require committing to disc. Dusapin's forthcoming opera, The last night (A Story of Faustus) has been commissioned by the Berliner Staatsoper and is due to be premièred in January 2006: an artistic highlight that will be eagerly anticipated.

Paul Conway

'Conciertos para el fin del milenio'. TOUSSAINT: Concierto No. 2 para violonchelo y orquesta (1999). MARQUEZ: Espejos en la arena (2000). SIERRA: Cuatro versos (Concerto for Cello \& Orchestra) (1999). Carlos Prieto (vlc), Orquesta de las Americas c. Carlos Miguel Prieto, conductor. Urtext JBCC 047.

Music-lovers who think of Latin-American 'classical' music through Revueltas, Chávez, Ginastera, Villa-Lobos - or, possibly, Guarnieri and Serebrier - are in for a treat with this collection of premiere-recording cello concertos. Clearly, a new generation is being recorded by its local talent, and it is time to prick up our ears. Mexicans Eugenio Toussaint (b.1954) and Arturo Márquez (b.1950) have crafted involving, richlycoloured, often outright gorgeous works based on popular sources: jazz and folk, respectively. The concerto by the Puerto-Rican Roberto Sierra (b.1953) is no less absorbing, while made of far grittier musical stuff. All were composed for Carlos Prieto, the dedicatee of works by about 70 other composers, including Joaquín Rodrigo. A student of Fournier and Rose, Prieto has performed in the world's major concert halls and even authored a biography (The Adventures of a Cello) of the Piatti Stradivarius he plays so engagingly on this disc.

Toussaint's Second Cello Concerto (1999) should make anyone who enjoys 'light classical' feel right at home. His earliest successes in jazz led to work alongside Herb Alpert and, later, as Paul Anka's musical director. When Toussaint embarked on this work, Prieto remarked that his First Cello Concerto had strayed from these roots, suggesting that he consider a return. The 
result is this breezy, approachable work showing a complete synchrony from the start between soloist and orchestra. Launching right into a vibrant tune, the expansive backup has the soloist sharing the stage with harmonizing forays by the flute, oboe, horns, strings and light percussion. In the slow movement, Prieto fills the spotlight with a nostalgic melody of longing while the winds underline, strings pluck a pulse, but little more. The cello and a clarinet switch into high gear for the conclusion, and in a cadenza Prieto jabs the work's light frame with rough-edged dissonance, invigorating the proceedings until xylophones, bongos and strings drive to the work's conclusion.

Fully in the swing of the work's idioms, Prieto's rich, deep tone does the composer proud even when required to sing at the topmost end of the cello's range. The work's strength lies in the lyrical middle, where the cello cries an aching tour de force, but, in keeping with its jazz roots, the main challenge, and this ensemble's remarkable achievement, is in expressing a sparkling spontaneity beyond the notated text. The infectious Latin flavour evokes Bernstein in mambo sleeves, rather than the more abrasive Pérez Prado, yet for all its upbeat charm and musicality, this work rewards repeated hearings.

The following work, Márquez's Mirrors in the Sand concerto (2000), places the soloist front and centre almost throughout, while the orchestra seldom strays from firm accompaniment. Márquez has an assured, extrovert voice, and reports folk forms in his blood since he learned the mariachi violin in childhood. A student of Federico Ibarra and Morton Subotnick, around 1990 he began drawing inspiration from Mexican folk music and has gained a following with a celebrated series of seven Danzones.

The orchestra's strident, almost regal canter in this concerto confirms dance forms as a Marquesian speciality: its sunny carriage resembles a Rodrigo score, while perhaps lacking his genial levity. This thicker rhythmic core frames Prieto's melodic elaborations, and the music emerges from this lyricism rather than from harmonic interplays. The expressive soloist gets support, emphasis and echo from the ensemble, ceding only rarely to a single instrument or section but never playing opposite them. Understated scoring again characterizes the slow movement Lluvia en la arena ('Rain in the sand'), where the cello plays a song of exquisite brooding that evokes Walton's concerto. The Milonga cadenza triggers a more agitated tempo, driving to a 'Right-left Polka' that propels the work with breathless, Shostakovich-like irony to the blistering finale.
Despite the enhanced percussion (claves, Veracruz tambourine, maracas and a PuertoRican güiro) this is a traditionally-orchestrated work centering on sturdy but graceful melodies, at which Márquez clearly excels. Supporting the cellist's virtuosic turn, the Orchestra of the Americas under Carlos Miguel Prieto makes fine work of inhabiting a neo-romantic sound-world that so differs from Toussaint's more spare, contrapuntal work.

A yet sharper change in character toward astringency and dissonance sets Roberto Sierra's Four Verses Concerto (1999) apart from both previous works, enriching this CD with a far more demanding avant-gardist work. To Márquez's celebratory dance or excursion, Sierra's concerto strikes the ear as a dark saga. While neither more nor less Latin in flavour and rhythmic core than the previous works, these are far more deeply integrated within Sierra's voice.

In stark contrast with Toussaint's concerto, cellist and orchestra begin by generating separate sonic cells, embarking at contrasting tempi from near-opposite ends of the scale. Straying far from the orchestra - which for once is given considerable autonomy - the cello wanders in pursuit of some musical concretion, to complete a worthy theme, or perhaps just content to roam. Its tension with the orchestra has no parallel on this disc.

While engrossed in its articulations, colourful sparks are set off by light percussion and winds, clashing against weighty horns, double-basses and darker woodwinds. Sierra's dazzling orchestral chaos is reminiscent of Thea Musgrave's brand of lucid and nimble disorder, and in the second movement it waxes and wanes with the cello's restlessness, yet never quite settling into accompaniment. A vague convergence does occur in a passage full of anticipation that culminates with the cello's soaring phrase (at 0:22); and when, duetting with various winds, the soloist entwines with a flute's phrase, and then completes it (at 3:02). But these moments always pass, the ensemble seemingly uninterested in the wayward cello. After an edgy cadenza, the strain of this aptly-named Intenso leads into a movement where the tensions slacken: the cello sets a less discordant direction for the straying woodwinds, percussion and disruptive brasses, and amid this more subdued backdrop the soloist takes on the nearprominence of a first among equals.

The dots so far strewn across the work start connecting in the vigorous Vivo, and in the jauntier Rítmico movements, overcoming the stark initial contrasts while never quite forsaking its character as an eerie and uncompromising 
music. A more recognizably Latin-American pulse begins supporting the soloist with energetic jabs and stresses, enhancing calmer moments while setting a quicker beat for the cello to rush toward an end that, unconventionally as ever, seems to arrive too soon - while curiously suggesting a satisfying resolution. Just prior to this, amid the rapid-fire playing, the work reaches the culmination it seemed at least partly driven towards (at 1:28), its moment of restful merging.

Sierra worked in Hamburg with Ligeti, yet this music shows as much affinity with Roberto Gerhard's for the seeming unruliness and for uniqueness: engaging the listener despite its high level of abstraction and the unbending avoidance of cliché. The likeness extends also to its difficulty: those so intrigued as to listen again may do so not for the ride or to be swept away, but for a better grasp of its startling wealth of tensions. Cuatro versos is clearly this disc's most bracing work, given its unusual ways of generating musical cohesiveness. For all the compositional strengths and musicality of the Toussaint and Márquez concertos, only Sierra's rightful kin are Lutoslawski, Gubaidulina and Dutilleux, placing him firmly in the 21st century.

The Orchestra of the Americas under Carlos Miguel Prieto (recorded in the Sala Nezahualcóyotl, Centro Cultural Universitario, Mexico City) adapts seamlessly to the challenging requirements, backing the soloist in the neoclassical Toussaint as a kind of rhythm section; joining the cellist's shaping of Márquez's melodic lines with bold but agile ensemble work; and rallying to the astringent Cuatro versos, with the wandering and ambiguities, and its unruly scoring. A tall triple order, but very handsomely met. All three composers owe a strong debt to Prieto's advocacy, yet each one repays by giving the Piatti a range of opportunities to display his gifts. In a field crowded by fine cellists, when instrumentalists with big contracts so often stay with the 'classics' or drift into pointless crossover, Prieto's discography includes impressive concerto premières by Federico Ibarra, Celso Garrido-Lecca, Camargo Guarnieri, and Ireland's John Kinsella - each of which leaves no doubt that 'classical' music is very much alive and thriving. Lovers of contemporary 'classical' will welcome Concertos for the End of the Millennium: three remarkable, well-recorded works spanning a wide musical spectrum. These sparkling performances by the Orchestra of the Americas, in the expert hands of both Prietos, deserve the highest possible recommendation.
BRAUN: Psalterion (2000); Day and Day (1998); Piano Trio No. IV (2002). Amber Trio Jerusalem, Eli Sassoon (santur), Edna Prochnik (mezzo-sop). Gramola 98766.

The compositional juggling of local and international idioms at the heart of much contemporary music is an aesthetic challenge thrown particularly into relief in modern Israeli music, which is concerned above all with a cogent balance of eastern and western elements. The issue is potently encapsulated in a recent work, Psalterion, by one of the leading composers of the second generation, Yehezkel Braun (b.1922), which combines a Persian santur with a western European piano trio, and Arabic modes with European harmony and forms. Braun is well known for his popular and prolific output of choral music, yet his oeuvre also includes an impressive array of vocal and chamber music as shown in a recent CD which features Psalterion, alongside a beguiling song cycle to poems by the poetess Yocheved Bat-Miriam (1902-80), and the dramatic fourth Piano Trio, Braun's most passionately complex trio to date. (Three earlier trios feature on a CD by the Amber Trio Jerusalem on the label of the Beth Hatefutsoth, Tel-Aviv and Jewish Museum, Vienna CC-005-0.)

The title Psalterion alludes to the 'psanterin' mentioned in the list of instruments in the Book of Daniel, a Greek word which refers to a type of lyre played with mallets, and which corresponds closely with a modern instrument known as the santur (interestingly the modern Hebrew for piano is 'Psanter'). Braun's interest in the instrument stems primarily from the wide musical influences he absorbed in Israel, where he came aged two in 1924 from his native Germany. Amongst his teachers was Alexander Uriah Boskovich, an émigré from Romania, who was particularly interested in evoking the sounds of the Middle-East. Braun, now Professor Emeritus at Tel-Aviv University, became an authority on Gregorian Chant. These twin influences, of middle-eastern melos and medieval plainchant, infuse his melodic-harmonic style alongside with the organum and parallel part-writing idiomatic to the French school of the late 19th century. While his large output frequently explores traditional music, this quartet represents something of a new departure for as he admits in the sleeve notes, 'Oriental and Western music are worlds apart, so different... that it is well nigh impossible to combine them. For me as a composer this was undoubtedly the most difficult task I have ever tried to tackle'. 
The melodic material of Psalterion is drawn directly from an oral tradition - performances by Braun's friend, the amateur santur player and Persian carpet dealer Eli Sassoon (the performer on this recording) - which Braun transcribed in detail, then integrated the result with piano trio (there is also an orchestral version). Both the first and third movements use the Persian 'Dashti' mode which is the same as the 'Maqam Bayat' or bayat mode, one of the most popular and important modes in Arabic folk music and used widely in Lebanon, Syria, Egypt and Iraq. Both outer movements also begin with a slow and free solo santur soliloquy which leads into a more rhythmic movement for the ensemble. The range of sonorities is both refreshing and imaginative: rather than westernizing the santur, the result is an orientalizing of the piano trio, with much use of high-registral cello and doubling melodies for strings, repeated-note textures, ornamentation and pedal points. Though there are moments which retrieve a Western sonority and sense of drama, as in the trio solos, the accent is on the imitation of santur by the trio. However the formal shape of the work is clearly Western in orientation, with clearly-defined contrasting sections, such as the shift from a slow undulating melody at the start of the central movement to a more waltz-like section, and the extended cadenza which launches the final rondo like finale.

If there are echoes of minimalism in the modal-tonal harmony and patterning, the main aesthetic issue arising from the piece concerns the integration of folk elements into art, or rather of local and international idioms: whether, like Maxwell Davies's use of an Orkney Fiddler in a symphony orchestra perhaps, such combinations create a self-conscious opposition of elements rather than a synthesis? Moreover, does such integration act as a bridge between cultures, or rather an appropriation of one idiom by anothera form of cultural imperialism? The answer here emerges from the work itself, which for me achieves a compelling symbiosis of disparate elements with a clear Eastern flavour, yet enhanced through the lucidity of its Westerninfluenced form. It is a stylistic balance through which beautiful sonorities and engaging dialogue amongst the instruments contribute to a uniquely innovative and enthralling ambience.

Malcolm Miller
BIRTWISTLE: The Axe Manual ${ }^{1}$; Oockooing Bird; Sad Song; Berceuse de Jeanne; Précis; Hector's Dawn; Ostinato with Melody; Betty Freeman: Her Tango; Saraband: The King's Farewell; Harrison's Clocks. Nicolas Hodges (pno), ${ }^{1}$ Claire Edwardes (perc). Metronome MET CD 1074.

In his review of the Collins Classics recording of Antiphonies for piano and orchestra, ${ }^{5}$ the pianist Nicolas Hodges drew attention to what he felt were numerous weaknesses in the soloist's performance. At times withering ('the piece would undoubtedly be more colourful in lyrical and brutal sections alike if the pianist could find it in herself to project Birtwistle's dynamics, articulation and phrase marks'), Hodges nevertheless emerges in his prose as a superb advocate of Birtwistle's music, in which intellectual and critical understanding co-exists with a deeply-felt emotional response. These latter qualities have characterized Hodges's own performances of Birtwistle's music, including his 2000 performance of Antiphonies. And, I am pleased to report, the same is true of his recent recording of Birtwistle's complete piano music.

Of the ten works on the disc, four are first recordings, the most important of these being The Axe Manual (2000) for piano and percussion. The colouring of the piano timbre through assorted percussion, moving from marimba to metal instruments and back again, contributes to the overall structure. By treating the percussion as an extension of the piano, there is a sense that only one meta-instrument is being used: the 'Manual' of the title alludes, amongst other things, to the imaginary composite of the keyboards of the piano, marimba and vibraphone within the work. Birtwistle also intended the piece to demonstrate a wide range of rhythmic devices; in this sense, 'manual' also means 'compendium'. Taken together, one can get a pretty good idea of what the piece is 'about'; that is to say, chamber-music like interactions between pianist and percussionist in which different (mechanic) rhythmic strata shift in and out of focus, engaging our attention. Hodges, along with Claire Edwardes on percussion, wonderfully capture the rhythmic and harmonic subtleties required of them, no more so than in a beautifully poised performance of the lyrical middle section: a hocket between vibraphone and the upper part of the piano proving to be especially captivating. 
Birtwistle's only other large-scale work for piano, Harrison's Clocks, is an even more intense exploration of rhythmic layers moving at different speeds. Hodges's virtuosic technique appeared to make light work of the first movement (reputedly the hardest of the set), but I found his impressive performance of the lengthier (and contrapuntally breathtaking) third movement in a single take to be the most rivetting.

The other eight works on the disc are considerably shorter, and on the surface simpler, than The Axe Manual and Harrison's Clocks, between which they are sandwiched. Ostinato and Melody takes as its basis the characteristic Birtwistle device of superimposing a melody over a constantly-changing ostinato. Another Birtwistlian trait is apparent in Betty Freeman: Her Tango and Saraband: The Kings Farewell, which both imaginatively distort the dances implied in their titles. The earliest work on the disc, and indeed, the earliest extant composition by Birtwistle, is Oockooing Bird, written in the composer's mid teens. As with the pieces for children with which it is grouped - Sad Song (1971) and Berceuse de Jeanne (1984) - the musical language is predominantly modal; this, combined with the use of ostinato, and the general melancholic atmosphere is prophetic of Birtwistle's later music. So too is the way in which Birtwistle disturbs the formal symmetries of Précis (1960) in order to create forward momentum. Hodges's performance of this is noticeably faster and at times more brittle than those of Stephen Pruslin ${ }^{6}$ and John Ogdon ${ }^{7}$ : as a result, is his a more urgent and volatile reading, but not without moments of poetry.

Thus these occasional works are no mere 'fillers' or curios, but rather miniature studies of the technical and aesthetic ideas that inform Birtwistle's larger works. They therefore shed interesting light on the major works, but this light also reflects back to give the smaller works increased depth. This is aided in the logical ordering of the works on the disc, not by chronology, but by artistic themes and concerns, as well as the fascinating discussion between Birtwistle, Hodges and Jonathan Cross in the CD booklet. This is a disc for anyone who admires Birtwistle's distinctive music, as well as for those who enjoy challenging but affirmative music performed with consummate musicianship.

Edward Venn

\footnotetext{
6 Clarinet Classics CC 0019.

7 EMI ASD 645.
}

DIAMOND: String Quartets (complete); Concerto for String Quartet; Night Music for Accordion and String Quartet ${ }^{1}$. Potomac String Quartet with ${ }^{1}$ Carmelo Pino (acc). 4-CD set (each disc available separately): Albany TROY 504 (Nos. 3 and 8, Concerto), 540 (Nos. 2, 9 and 10), 613 (Nos. 1, 5 and 6) and 727 (Nos. 4 and 7, Night Music).

David Diamond died on 13 June 2005 less than a month short of his 90th birthday, and just after the release of the final instalment of this first integral set of recordings of his String Quartets, the most monumental by any American and almost certainly the finest cycle in the medium for consistency of quality, clarity of thought and elegance of conception to emerge from the left hand side of the Atlantic, and worthy of comparison with Holmboe, Simpson and Shostakovich.

Diamond's fascinating life experience, and his vital encounters as an impressionable young man with so many great artists and composers in 1930s Europe and America, left indelible imprints on his creative nucleus and his music has paid consistent homage to the great ideals of clear classical linearity and architectural transparency. In many ways the ten String Quartets written between 1941 and 1968 (11 if one includes the 1936 Concerto for String Quartet, a spontaneous youthful offering generated by and dedicated to Albert Roussel), mirror the even more massive cordillera of Diamond's symphonies, the last of which (No. 11) appeared in 1992. Diamond has also written a Concerto for String Quartet and Orchestra (1995), a return to the medium after nearly three decades.

Taken in their chronological context the quartets mirror his stylistic evolution: the first three date from the 1940s, a period of serene modality and diatonic repose which also witnessed the first four symphonies, Rounds for strings and the Piano Concerto and Piano Sonata (both of these still unrecorded, alas). The depth of feeling found in the long Adagio of the Second Quartet, an elegy to a female painter who died at the age of 31 , points the way to the sudden transition to the much greater intensity of the Fourth Quartet (1951), written during the early part of Diamond's 15-year residence in Italy. On the surface, the texture seems anxious and disturbed, but the apparent disorder is little more than a mask for the underlying structural integrity and formal discipline. Diamond turns again and again to the variation form (the last movement alone of this epic 40-minute essay comprises ten variations lasting 15 minutes). 
Diamond had met Arnold Schoenberg in the 1930s in New York and recognised the vast new possibilities opened up by his advocacy of the 12tone method. Diamond grasped immediately that this was a technical tool, not an end in itself, and thus he has been able to use it to as great or less an extent as his creative needs required. Each quartet has its own distinctive personality, and no less than three are $70^{\text {th }}$ birthday presents to other composers he admired: Walter Piston (No. 7) Roger Sessions, a former teacher (No. 9) and Darius Milhaud (No. 6). No $9(1965-68)$ is one of only two in a single-movement format (the other is No. 1) and is a feast of ornaments and trills, which Diamond says (in an illuminating series of interviews reproduced in the sleeve notes) gave him the chance to bring out the individual instruments by strict dynamic markings. A flavour of Sessions's sometimes elliptical language finds its way into the piece. The same (dynamic) directions appear in the numerous fugues (another favourite format) found in many of the quartets, the finale of No. 8 being an especially fine example.

As Diamond's style evolved so it began to 'revolve', and some of the raw intensity of the 1950s (a difficult time for him with much soulsearching) yielded to a less edgy language, without loss of intensity. Pieces like This Sacred Ground for choir and orchestra (1962) and Night Music for accordion and string quartet (1961) indicate a composer more at ease. Night Music is a gem, a brief nocturne in memory of Wallingford Riegger, another (still underrated) American composer Diamond admired, killed in a strange accident in New York. The unusual instrumentation is what captivates. The quartets from the 1960s (six in all) are all mature works, and the Tenth (1966), written for a new faculty building at the American University in Washington, seems an apt summation, ending with brilliant double fugue. Diamond had by then returned to America for good, and embarked upon a second career as an academic, holding many important positions at The Manhattan School of Music and The Juilliard School until he finally retired in 1997.

This magnificent set of recordings will bring alive a great musical treasure for whoever is moved to investigate it. The members of the Potomac Quartet have taken the composer and his music to their hearts. Thanks to these four CDs, along with the superb series of orchestral works recorded some years ago by Gerard Schwarz and the Seattle Symphony - now all reissued at budget price on the Naxos American Music Series (with, hopefully, as rumour has it, some further new recordings to be added soon from that quarter) - Diamond's importance and stature, not only as a leading figure in America but as a major composer for all time, is assured. Despite the sadness of his passing, at the very end of his life his music will now live on to encapsulate his lifelong quest for the beauty of perfection.

Bret Johnson

HOWELL: Violin Sonata in F minor; Rosalind for violin \& piano; Piano Sonata in E minor; Humoresque for piano; 5 Studies for piano. Lorraine McAslan (vln), Sophia Rahman (pno). Dutton Epoch CDLX 7144.

BACEWICZ: Violin Sonatas Nos. 4-5; Oberek No. 1; Sonata No. 2 for violin solo; Partita; Capriccio; Polish Capriccio. Joanna Kurkowicz (v;n), Gloria Chien (pno). Chandos CHAN 10250.

MARIC: Byzantine Concerto ${ }^{1}$; Cantata: Threshold of Dream ${ }^{2,3,6}$; Ostinato Super Thema Octoïcha ${ }^{4-6}$; Cantata: Song of Space. ${ }^{1}$ Olga Jovanovic (pno), Belgrade PO c. Oskar Danon, ${ }^{2}$ Dragoslava Nikolic (sop, alto), ${ }^{3}$ Jovan Milicevic (narr), ${ }^{4}$ Ljubica Maric (pno), ${ }^{5}$ Josip Pikelj (hp), ${ }^{6}$ Radio-TV Belgrade CO c. Oskar Danon, ${ }^{7}$ Radio-TV Belgrade Mixed Choir \& SO c. Mladen Jagušt. Chandos Historical $10267 \mathrm{H}$

MUSGRAVE: For the Time Being: Advent ${ }^{1}$; Black Tambourine ${ }^{2-3}$; John Cook; On the Underground Sets 1-3. ${ }^{1}$ Michael York (narr), ${ }^{2}$ Walter Hirse (pno), ${ }^{3}$ Richard Fitz, Rex Benincasa (perc),New York Virtuoso Singers c. Harold Rosenbaum. Bridge 9161.

KUI DONG: Earth, Water, Wood, Metal, Fire'; Pangu's Song $^{2}$; Blue Melody ${ }^{3}$; Crossing (electronic/computer tape music); Three Voices ${ }^{4} .{ }^{1}$ Sarah Cahill (pno), ${ }^{2}$ Tod Brody (fl), Daniel Kennedy (perc), ${ }^{3}$ San Francisco Contemporary Music Players c. Olly Wilson, ${ }^{4}$ Hong Wang (Chinese fiddle), Ann Yao (Chinese zither), Chen Tao (bamboo fl). New World 80620-2.

FIRSOVA: The Mandelstam Cantatas: Forest Walks, op. 36; Earthly Life, op. 31; Before the Thunderstorm, op. 70. Ekaterina Kichigina (sop), Studio for New Music Moscow c. Igor Dronov. Megadisc MDC 7816.

KATS-CHERNIN: Ragtime \& Blues. Sarah Nicholls (pno). Nicola Sweeney (vln). Signum SIGCD058.

CHAMBERS: A Mass for Mass Trombones. Thomas Hutchinson (trb), Ensemble of 76 trombones c. David Gilbert. Centaur CRC 2263.

Dame Ethel Smyth aside, Dorothy Howell (1898-1982) was the doyenne of English women composers. Ten years older than Elizabeth 
Maconchy, she studied with J.B. McEwen at the Royal Academy of Music (where she was later a Fellow and Professor of Harmony, Composition and Counterpoint) and established herself as a composer - one critic hailed her as the 'English Strauss' - in the years immediately following the Great War. Today her reputation, such as it is outside the RAM and the Elgar Society (on whose behalf she for many years tended Elgar's grave), rests on the Phantasy for violin and piano which won her the 1921 Cobbett Prize, her only piece to keep even a finger-nail's hold in the repertoire since then. It crowns a thoroughly engaging programme of Howell works for violin and/or piano. As both the longest single span on the disc and the strongest work present, the Phantasy makes a fitting climax. In her booklet note, Celia Paterson refers to its 'soaring melodies and arclike phrases, flowing rhythmical patterns and extensive use of thematic ideas and motifs which unify the overall structure', as good a description of the piece as any. At another time, it could have been titled Sonata and bears consideration as a free-format single-span example of the form.

Howell did formally compose a Violin Sonata, in $\mathrm{F}$ minor and three movements, but only in 1947 , after she had faded from view, like so many others whose reputations had been made before the Second World War. Stylistically, Howell's music never advanced beyond late Romanticism but she eschewed the opulence of contemporaries like Bax, so that her voice was rather restrained. The Sonata is a case in point: lacking the drama of the Phantasy it is possessed of an enviable poise. I prefer it to either of the saccharine miniatures, Rosalind (1920) and The Moorings, though both have a winning salon-like charm and, throughout, McAslan phrases the solo lines beautifully. The $\mathrm{E}$ minor Piano Sonata is later still (1955), again in three movements, and unashamedly melodic, its heart lying in the central Ninna-nanna, evocative of a cradle's rocking motion. Howell died childless but had a love of children, so it may not be too fanciful to suppose that the sonata as a whole has something of the young in its make-up. Of more weight, though lesser in length, are the Five Studies Howell composed when a RAM Professor. These are highly accomplished pieces, two or three having a stature beyond their relatively modest proportions, the exuberant final Allegro not least. It matches the nature and virtuosity of the earlier Humoresque (1919), one of Howell's most electric smaller pieces, the demands of which Sophia

\section{hcmf}

\section{7-27 November 2005}

Guest Artistic Director, Tom Service, presents an intriguing programme of over 50 events at the 28th Huddersfield Contemporary Music Festival

\section{First Night}

Freiburg Baroque Orchestra perform new pieces written for them by Rebecca

Saunders, Michel van der Aa, Juliane Klein, Benjamin Schweitzer and Nadir Vassena

\section{British Focus}

Including works by Christopher Fox, James Dillon, Sam Hayden, Michael Finnissy, Chris Dench and Joe Cutler

\section{Norwegian Feature}

Series of 7 concerts featuring BIT:20,

Cikada, Asamisimasa and Nordic Voices; works by Rolf Wallin, Lasse Thorensen and Eivind Buene

\section{Japanese Focus}

Works by Jo Kondo, Misato Mochizuki, Takeo Hoshiya and Norio Nakagawa; London's Philharmonia Orchestra present programme by Toshio Hosokawa

\section{Giacinto Scelsi}

100th anniversary celebration featuring the New London Chamber Choir, Mieko Kanno and Ensemble Nomad

\section{International Highlights}

Neue Vocalsolisten Stuttgart, Agrare, Pokrovsky Folk Ensemble, Opus Posth, Diotima Quartet, Ensemble Recherche, Claire Edwardes, Ives Ensemble

\section{Last Night}

Ensemble Modern perform a major new work by Helmut Lachennman

Info/brochure:

T 01484425082 or www.hcmf.co.uk Box Office: T 01484430528

(opens 24 September)

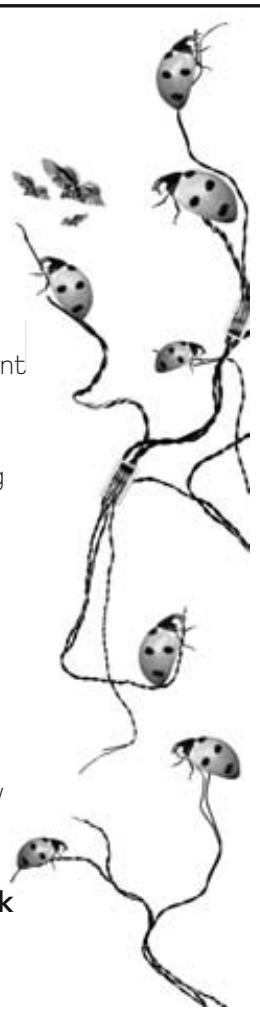


Rahman proves equal to. Dutton's sound, engineered by Tony Faulkner and recorded in the Henry Wood Hall, is spacious but intimate. An appealing disc, which deserves every success.

Grazyna Bacewicz (1909-1969) is best known today as a composer of some of Poland's most vibrant music in the mid-20th century, but she made her international reputation in her midtwenties as a performer when she came third although only behind Ginette Neveu and David Oistrakh - in the 1935 Wieniawski International Violin Competition. She was an accomplished enough pianist, as Judith Rosen recounts in the booklet, to première her own piano concerto. (And in the same concert as one of her own violin concertos!) After the Second World War, however, it was as to composition that she increasingly devoted her time, largely retiring from public performance in the mid-1950s and winning many composition awards.

Despite her reputation, her tally of 200-plus compositions, and the renown of the best-known of these, the Concerto for strings (1948), Bacewicz's discography is modest, recordings mostly of Eastern European provenance often on specialist import labels. Joanna Kurkowicz's and Gloria Chien's programme of seven of her betterknown works (all bar two are listed as available in the 2005 R.E.D. Classical Catalogue) catches both the steel and sensitivity of her music. In the Fourth Violin Sonata (1955), Kurkowicz and Chien are exemplary executants, taking a little more time over the music than previous versions and allowing it to breathe. Whilst losing nothing of its leanness, they reveal its gravity better than did, for instance, Statkiewicz and Utrecht on Olympia (OCD 392). They catch the shades of Bartók and Shostakovich that suffuse all four movements - just as vital as those of Debussy or Franck spotlighted by Rosen - whilst emphasizing the lyrical qualities of the work, as in the Andante ma non troppo second movement.

Bacewicz's Fifth Sonata (1951) - not otherwise available on disc - is more compact, playing for less than 14 minutes in this bracing account. If No. 4 (here almost 21 minutes) shows Bacewicz as master of the Classical four-movement sonata structure, in the turbulent Fifth she follows a more severe, tripartite form, the music elusive in character although the central Andante dolcissimo is lovely. There is, throughout, a good deal of power-by-suggestion, especially in the concluding Allegro inquietamente. The idiomatic leap from this to the Second Sonata for Violin Solo (1958: a work which the composer came out of retirement to première), is extraordinary. Gone are the folk inflections of the earlier pieces, replaced by more abstract expression and tonal ambiguity, not least in the bold, Adagio opening bars, underscoring the severity of the instrumental line. The reason for its more advanced traits lies in the cultural thaw instigated by the Communist regime in Poland, which permitted composers such as Baird, Lutosławski and Penderecki to create some of their most characteristic music. For Bacewicz, the liberating effect extended to the 'how' of performing technique as much as what notes to write. Perhaps in the development of the Allegro first movement proper there is too much reliance on repeated patterns, though the way Bacewicz modifies and extends the tail sections of these carries more than a hint - unknowingly, I think of the minimalism that would sweep Western music seven or eight years later. For all its apparent abstraction, the tense central Adagio is very evocative, while the squall that comprises the concluding Presto carries something of protest about it.

Whether Bacewicz had a political agenda will probably never be known, although clues may lie in the Partita for violin and piano (the other work not otherwise available on $\mathrm{CD}$ ) written three years earlier. The marking of the opening Preludium - Grave tells you all you need to know about its character, while the desolate Intermezzo, Andantino melancolico, suggests some personal inspiration behind the notes. In between comes an initially jaunty Toccata, marked Vivace. By the time its three minutes have concluded it seems more than a touch manic, as if infected by the tragic demeanour of the movements framing it. The concluding Presto breathes a different, more relaxed air, as if finally free of despair. Kurkowicz, ably supported by Chien, gets to the heart of Bacewicz in both the Second Sonata and the Partita in ways I have not heard other performers achieve. But the programme is not all doubt or conflict - there are three delightful miniatures, Capriccio (1946), Oberek No. 1 (a species of fast mazurka), and the title track, Polish Capriccio (both 1949), all written as virtuoso or encore pieces and displaying Bacewicz's lighter, brilliant side. An utterly splendid disc, especially given Joel Gordon's sensational engineered sound, and I hope Chandos delve further into her extensive collection of music.

The same label deserves much praise for their historical disc of the Serbian composer, painter, sculptress and author Ljubica Maric (1909-2003). Her remarkably long life was one of almost perpetual political and personal upheaval, from the death of her father when she was just four years old through the horrors of two world wars, the formation and disintegration of Yugoslavia 
and the cultural oppression of the communist regime. Her music ranged stylistically from folkderived simplicity to microtonal experimentation (she was a highly regarded student of Alois Hába in Prague in the 1930s - she turned down the chance of becoming his assistant - as well as of Josef Suk and Hermann Scherchen) but much of her earlier music was lost through the vicissitudes of war in central Europe. Chandos's disc features four works from the post-war period in archival recordings from Serbian Radio and TV dating from 1964, except that of the large-scale cantata Song of Spaces (1956), often cited as her most important work (and apparently much admired by Shostakovich), which is from 1977 . The earliest work on offer, Song of Spaces is a remarkable choral-and-orchestral tapestry setting funerary inscriptions of the medieval Bogomil sect. This Christian offshoot was based geographically in Bosnia-Herzegovina but theologically in Manichaeism; on their tombstones they recorded their heroism and fealty to lord and God with imprecations not to disturb their bones. From these Maric wove a work full of vivid drama and symphonic movement and the performance by the Mixed Choir and Symphony Orchestra of Belgrade Radio-TV under Mladen Jagušt matches the white heat of her music. If the sound quality is not first rate it is certainly in no way problematic, with good depth and little distortion in the upper registers or louder, fuller passages.

It has been suggested that Maric disguised or sublimated her pre-war avant-garde idioms in music ostensibly looking backward into Serbia's past, especially in those works based on Byzantine music. Her interest, however, strikes me as genuine enough, as can be heard in her other major large-scale project, the cycle of four works based on the Octoëchos, a volume of medieval Serbian sacred music derived in turn from Byzantine liturgical modes. Maric used these scales and modes as a reservoir in this tetralogy of secular works, three segments of which are included on Chandos's disc. The single-span orchestral Octoïcha I is missing but something of its nature can be gleaned from the Byzantine Concerto (1959), a three-movement work for piano, brass, strings, harp and percussion which grew out of the orchestral role the piano played in the earlier piece. A "homage both to our Byzantine heritage and our cultural roots', according to the composer, who alerted listeners also to the use of hexachords in the musical fabric and how 'two connected transpositions of the hexachord generate a total of twelve chromatic tones'. However, there is nothing dodecaphonic in the static progress of the opening span, Sound and Ringing, while the close of the atmospheric, lowering second movement, In Darkness and Glimmering, was inspired by early Truffaut. Only in the finale, Roaring and Glaring, does the music's character depart from its title, despite the best efforts of Olga Jovanovic and the Belgrade Philharmonic Orchestra under Oskar Danon. There is some scrappiness of ensemble and intonation here indicating that the music was a touch beyond them, but this is a determined and not unmoving account of a powerfully evocative score.

The remaining two parts of the cycle are both considerably shorter, the intense chamber cantata Threshold of Dream (1961) and the instrumental Ostinato super Thema Octoicha for piano, harp and strings (1963). The cantata sets surrealist poetry by Marko Ristic 'raising the question of the meaning and dissolution of life and its ultimate sense'. Scored for soprano and alto voices (both roles being sung here by the same singer, Dragoslava Nikolic), male narrator - Jovan Milicevic here produces a sound close to that which Penderecki would require for his St Luke Passion a couple of years later - and chamber orchestra, Threshold of Dream is much less immediate in effect than either the Byzantine Concerto or Song of Spaces. By contrast, Ostinato super Thema Octoicha, here performed magically by Maric herself with harpist Josip Pikelj and the Belgrade Radio-TV Chamber Orchestra under Oskar Danon, is gripping from first bar to last in its opposition of obsessive tranquillity (centred mainly on the piano) and agitation (the strings). According to the composer this 'echoes the words in the score: "In moving it stands still - in standing still it moves"”.

Although long-resident in the United States, Thea Musgrave is one of Britain's best-known and most distinguished women composers. Were there any doubt of this the American Bridge label's disc of six choral works would soundly expel them. The largest single span is a setting of the opening section of Auden's 'Christmas Oratorio' For the Time Being. Auden wrote the poem for Britten but neither he, nor any later collaborator (including Henze), set anything more than small sections. ${ }^{8}$ Musgrave's cantata,

\footnotetext{
8 Auden's poem, however, has been tackled several times by others in North America. The New York-born Martin David Levy (b. 1932) set the poem in 1959 apparently Leonard Bernstein was much impressed) and the Canadian Chester Duncan (1913-2002) created two works derived from it, incidental music for a 1965 radio broadcast, later expanded into an oratorio. The most recent setting is by John Scott, the choral director of Acadia University, Nova Scotia, scored for double choir, cello and percussion and premièred in Halifax, NS, on January 21 this year.
} 
titled in full For the Time Being: Advent, dates from 1986 and extends for over 25 minutes. A rich a cappella choral tapestry, its three large spans eloquently catch the ambiguities and uncertainties of Auden's wartime verse. In the central span the chorus turn accompanist to a narrator - here Michael York, with nicely judged delivery avoiding the histrionic - who declaims, with increasing emotion, the second of the section's three spans. The chorus here divide into male and female voices, reprising passages from the first section, towards the close threatening to overwhelm the narrator. This is one of the subtlest settings of Auden I have encountered, on a par certainly with Britten's Our Hunting Fathers and Henze's Sicilian Muses and engaging on a much deeper level than Bernstein's Age of Anxiety Symphony.

There are Brittenish resonances in the third segment of Musgrave's triptych On the Underground (1994), settings of stanzas that over the past 15 years or so have been printed alongside advertisements in London's famed subterranean transport system. A Medieval Summer is, unlike the other two segments, a single span (lasting almost 12 minutes) built around a passage of Chaucer welcoming summer into which other similar estival texts (including Sumer is icumen in, so memorably set by Britten in the Spring Symphony) are woven. As a piece of literature it is impressive enough, but Musgrave's setting catches all the heat and languor of the season. The previous two sets also bear themes, the first On gratitude, love and madness - setting six poets of diverse provenance, including Stevie Smith, Yeats and Emily Dickinson - and the second The Strange and the Exotic, where the anonymous I saw a peacock with a fiery tail and Edwin Morgan's The Subway Piranhas are framed by a couplet of Herrick's.

Those unfamiliar with Musgrave's idiom would do well to start with the cycle Black Tambourine (1986), a cycle of six poems by Hart Crane set for women's chorus, piano and percussion (played ideally by the chorus members but here by Richard Fitz and Rex Benincasa). No two movements have similar textures - the third, Black Tambourine, includes a narrator - with the accompaniment varying from piece to piece. As Malcolm MacDonald points out in the booklet, here Musgrave utilized a more direct melodism than in other works of hers, though the whole set is evocatively harmonized: listen to the glacial opening North Labrador or the delightful miniature fifth movement, Pastorale. The cycle is a tour de force amongst tours de force and sets the New York Virtuoso Singers decidedly on their mettle. They rise to the challenges of all the works here, completed by the tiny part-song John Cook (1963), ably directed by Harold Rosenbaum. Bridge's recording is sympathetic and crystal clear. While not yielding all its secrets in one or even five hearings, the whole is a joy to listen to.

Elena Firsova (b. 1950) is another composer badly served by the record industry, so full marks to the Belgian Megadisc label for collecting three of her cantatas-cum-song cycles on texts by Osip Mandelstam. The disc's title, The Mandelstam Cantatas, might suggest a complete survey but in fact the three works here constitute less than half of Firsova's settings has made of her 'favourite poet and the one to whom [she] feels closest'. Mandelstam's texts and sensibilities can be felt throughout her musical output. 'His poetry is written in precisely the way I would like to write music', she has said and these works, which she regards as her most important, are eloquent tribute to her love and deep communion with his writing. The earliest is Earthly Life (1984), cast in five sections of varying lengths (the most substantial being the finale, as in all three works here) to texts drawn from Mandelstam's collections Stone, Miscellaneous Poems and Tristia. Firsova's vocal style - and not a little of the accompaniment - has its roots ultimately in late Shostakovich. Firsova's pared-down textures fit the verse perfectly, from the 'tense and hollow sound of fruit falling from a tree' to the 'circling choral dance of shadows that trampled the soft meadow'. There is something in the music of that strange acoustical effect when the snow is on the ground, a dampening of emotion that becomes all the more intense for its restraint.

That sense of atmosphere recurs to very different ends in Forest Walks (1987), by contrast a diptych setting two further poems from Stone. Here music of rapt beauty illuminates Mandelstam's icy and rather gloomy forestscapes, where loneliness and sorrow are carried like a bird which might be shot on the hunt at any moment. The longer second span acts like a lens on the matter of the opening Lento (the movements in all the works bear only tempo markings in lieu of titles). Something similar occurs in two stages in the final pair of movements of Before the Thunderstorm (1994), although this cantata opens with a short instrumental Adagio, which gives way to a series of musical thumb-nail sketches of characters from Mandelstam's Moscow Poems. This gives way to altogether more apocalyptic visions of Russia's past with a recurrent theme of a son cut off from family, perhaps mirroring the poet's own periods of internal exile. Here and there come occasional flashes of Britten in the textures (listen for 
instance to the horn writing as much as the voice in the Maestoso fourth span) and it is not fanciful to place Firsova's cantatas in the same league as the Suffolk master's Serenade, Nocturne or Phaedra. Soprano Ekaterina Kichigina sings on the whole beautifully, sounding a touch shrill in upper registers, and she is accompanied superbly by the Studio of New Music Moscow under Igor Dronov. The recordings, made in Moscow in April and May 2002, are first-rate. An excellent disc which I urge all lovers of vocal repertoire to try.

Despite containing pieces entitled Pangu's Song and Three Voices, the music on New World's disc devoted Kui Dong (b. 1966) is instrumental - well, up to a point: two movements of her electronic tape/computer piece Crossing (1999-2000) feature voices (including her own in a song learnt in childhood). Like her compatriot Chen Yi, Kui Dong emigrated to the US from China to further her education and qualified from Stanford University. Her works have been performed around the world and received numerous honours and prizes. Her style is a fusion of elements from Chinese traditional and Western avant-garde music, in range covering ballet, film, orchestral, instrumental, multi-media and electronic scores. The earliest here is Blue Melody (1993), a variation-form quintet for flute, clarinet and piano trio. There is no theme as such; rather each variation takes the opening paragraph (in which the instruments only gradually enter) as a kind of thematic reservoir to evolve their own substance. The result sounds like controlled improvisation - something close to her heart and she has used her own extemporizations as springboards for several works, as in the piano suite Earth, Water, Wood, Metal, Fire (2001). Each movement is a kind of portrait of its element, from which the ancient Chinese believed the world was constructed. Naturally, the five pieces are highly contrasted, Earth strong and solid, Water delicate and shimmering (and not unlike some of Takemitsu's rain pieces), while in Wood and Metal the composer requires pencils and triangle beaters (placed between the strings) respectively to provide a slightly 'prepared', additional range of sonorities. The work's strength is its diversity, much being drawn together in the blazing finale, Fire, before gently returning to the cycle's opening by way of close.

The duo for flute (doubling on the alto) and percussion Pangu's Song (1998) won the 2001 ISCM composition competition and requires the wind player to navigate through a kaleidoscopic mosaic of textures across the entire instrumental range. Playing for around nine minutes, it possesses a succinctness which the electronic suite Crossing does not attempt to emulate. Here, maximalism is all, centring on a 'head-on culture clash' in the central movement, where pounding rhythms and industrial sounds morph gradually into a manic rock-type music with electric guitar and drums, before a bizarre Chinese-sounding coda. The final span is the most Oriental in atmosphere, evocative perhaps of the composer's childhood. The trio Three Voices (1998), however, is scored for traditional instruments: er-hu (a fiddle), zheng (a species of zither with an almost harp like sound) and di or xiao (a bamboo flute). The music, though, is quite original: Kui Dong highlights the very different kinds of sounds these instruments make in what amounts to a mesh of accompanied solos, rather than the dialogue of conventional Western chamber music. The sonorities are enchanting, nonetheless, the playing mesmeric. Indeed, the performances are all well focussed and Sara Cahill's of the piano suite and Tod Brody's flute in Pangu's Song are brilliantly virtuosic. New World's recording is nicely balanced throughout and fairly homogeneous, despite the pieces having been set down in three different locations from California to New York.

Elena Kats-Chernin (b. 1957) is another composer from the East who has moved to the West, although in her case from Tashkent in Uzbekistan to Australia and Europe, between which two continents she now divides her time. She is, nonetheless, now regarded as one of Australia's leading composers and has received a good number of commissions in her adopted homeland. She was a recipient of a Peggy Glanville-Hicks scholarship in 1997, allowing her to spend some time in Britain, during which time she developed further the writing of short, relaxed miniatures, many in the style of ragtimes, 24 of them being gathered on Signum Classics' disc Ragtime \& Blue. Kats-Chernin has found this type of activity something of a therapy when writing large-scale or more serious scores, often through re-using discarded material from other works. The first such piece, Russian Rag, actually dates from the previous year (1996) and was specifically commissioned for a recorded anthology of modern rags. A small-orchestral arrangement was featured on $\mathrm{ABC}$ Classics' splendid all-Kats-Chernin CD, Clocks (ABC 456 468-2) but here is played evocatively by Nicola Sweeney and Sarah Nicholls. Several later pieces derive from discarded ideas from Russian Ra,g while several others here are arrangements or transcriptions of ideas from stage works. Green Leaf Prelude, Eliza's Aria, Brothers and Mute Princess all originated in Kats-Chernin's award-winning 
ballet Wild Swans (2002-3), about an imaginative young princess (Eliza) who has eleven boisterous brothers - at one point she has to knit jumpers for them out of nettles! The wistful Reflections comes from her theatre piece $\mathrm{Mr}$ Barbecue and describes the protagonist's feelings at seeing himself turn into his father in a mirroir (as he shaves). Both Nostalgic Piece and Suburban Rag were penned primarily as incidental music (the latter for a production of Uncle Vanya, no less) while the lively Slicked Back Tango - alternatively known as the Kosky Tango - was written for a film about the theatre director, Barrie Kosky.

Other pieces here came about through episodes in the composer's own life, such as the gentle Get Well Rag, written during the illness of one of her sons, and Revolving Doors (2000) composed after visiting her publisher in New York and an - obviously not entirely happy - encounter with several sets of these entrances which prompted this light-hearted if uneasy miniature. The bright Sapphire Rag was written expressly for Kats-Chernin to perform in public, while the most recent - Cocktail Rag (2004) - and Birthday Rag were composed for friends. One of the few really dramatic pieces is Bucharian melody, prompted by memories of her mother who was once an optician in Bokhara (Buchara): this is one of the few pieces here that betrays the composer's Uzbekistani roots. Nicholls and Sweeney (who plays in about two-thirds of the pieces) do the music proud, with just the right mix of lightness and gravitas. Nicely recorded (in the Henry Wood Hall, London, this January) there is much to charm here, but when heard through in a single sitting I for one was left with a feeling that greater matters were deliberately being avoided.

One such great matter might be a composition of a requiem for one's own father, but I doubt that even as mercurial a composer as Kats-Chernin would respond with something as quixotic as $A$ Mass for Mass Trombones (1994), a nine-movement requiem for solo trombone accompanied by an 'orchestra' of - wait for it - 76 trombones, written by Wendy Mae Chambers (b. 1953). Chambers has made a reputation for herself from the unconventional, whether as the inventor of the car-horn organ, a performer on the toy piano, or as the composer of works for massed forces. Previous examples include Music for Choreographed Rowboats (1979) for 24 musicians afloat in Central Park, Ten Pianos (1983), and The Great Harp Event (1984) - involving 30 harpists! Then again there is her Symphony of the Universe (1989) for horn, 100 timpani, metal percussion, jazz band, choir and tape, or her 'voodoo tone poem' Twelve Squared $\left(12^{2}, 1994\right.$, issued on New
World 80526-2) for a dozen percussionists. Other pieces have been written for 30 trumpets and for 26 marimbas, so clearly Chambers is a composer who does nothing by halves.

The use of trombones was suggested, unsurprisingly, by Berlioz's use of them in his Requiem, but Chambers's creation of a trombone orchestra, divided into 11 choirs, goes far beyond even that great experimenter's wildest imaginings. The music, though, is not especially revolutionary: stern, stark at times with an awesome grandeur that has its roots in the American pioneer tradition (think perhaps of Roy Harris at his most grandiose and sombre), though shot through with a mild exoticism that reminded me of Hovhaness. Chambers even makes use of an Armenian chant in the Sanctus as well as the great medieval plainsong in the Dies Irae. Although running in this live performance for over 70 minutes, the work does not pall or outstrip the limitations of the instrumental textures any more than did the gongs in Cecilie Øre's hypnotic opera A.. Thomas Hutchinson proves a most eloquent soloist here, and David Gilbert directs this extraordinary ensemble, recorded in the Cathedral of St John in New York, with great skill.

Guy Rickards

RICHARD ALLAIN : 'When I'm Gone' - choral works performed by Laudibus (Chamber Choir) and National Youth Choir of Great Britain, c. Mike Brewer. Delphian DCD34026.

A composer of many parts, encompassing liturgical, sacred choral music, music theatre, with some jazz influence, and an aptitude for writing works for children, Richard Allain (born 1965) has been described as one of the most creative musical voices of his generation. I first heard his emotive Salve Regina for eight-part unaccompanied chorus in a live performance in $\mathrm{St}$ Albans (March 2004), by the local Carillon Choir conducted by Simon Johnson, Assistant Master of Music at St Albans Abbey. Composed in 1992 in memory of a friend of the composer who was killed in a car accident aged 22 , the piece was first broadcast in 2000 by the BBC Symphony Chorus (2000), followed by its Proms debut, sung by the National Youth Choir, of whom Allain became composer in association in 2003. This work is quite outstandingly compelling to the ear, as well as repaying closer scrutiny of its carefully-crafted structure. It has just been released on $\mathrm{CD}$ on the 
Delphian label, with excellent notes by Tarik O'Reagan, who extols the virtues of Allain's 'unique musical dialect' and 'delicate juxtaposition of order and freedom'. Allain himself cites the influence of Arvo Part, describing Salve Regina as 'stripped of needless complexity and full of the sounds I remember from the Church I attended as a child'.

Salve Regina opens almost imperceptibly, rising to a great crescendo of intensity of sound, well realized in this premier recording by the National Youth Choir, whilst still managing to retain an essentially querulous texture amidst excellent projection and sound quality. At the harrowing words 'in hac lacrimarum valle', from the traditional 12th-century monastic text, the choir breaks into supplicatory 'whispers', subtly interlacing the words 'tuos misericordes oculos' and 'nos converte' repeatedly, above the slowmoving tenors and basses, to mystical effect. As Allain explained to me when he attended our local St Albans live performance: 'I remember as a child hearing people saying the rosary in side chapels in the church, and the repetition of litanies in alcoves aside,' and it was this perpetual offering-up of whispered prayer which inspired his 'whispering' sequences in the piece. I asked him about the harmonic structure: 'The harmony is in fact based on jazz voices, so sounds modern'. I noted too a distinctly dramatic intensity to this work, particularly the last section, akin to the immediacy of an operatic score or theatre music, which no doubt reflects his previous work for Covent Garden Opera.

Other works on his latest Delphian CD include a strikingly exotic piece, At Night I seek the one my Spirit loves, based on the biblical 'Song of Solomon' and scored for soprano saxaphone (played by John Harle),voice and organ; and the liturgical Missa Brevis, first commissioned by Simon Johnson and St Albans Abbey Girls Choir and beautifully delivered here by Laudibus Chamber choir. I found the 23-minute Improperia a very valid Good Friday liturgical piece, based on Christ's reproach of His people for driving him to His Passion after all God had done for them - but a little too lengthy for inclusion on a mixed genre CD. Although impeccably performed, encompassing plainchant, polyphony and innovative use of chord-clusters, the seemingly endless succession of anticlimaxes in the plainchant, even to a seasoned practising Catholic like myself, palled after a while, however evocative they may be of tradition; in the context of a modern work one expects more progression on a 21 st-century CD. That said, I can thoroughly recommend this disc for excellent sound-quality, the choirs well conducted by Mike Brewer, and some of the most compellingly innovative works I've reviewed on $\mathrm{CD}$ to date.

Jill Barlow

ADÈS: Piano Quintet ${ }^{1}$. SCHUBERT: Piano Quintet D667, The Trout ${ }^{2}$. Thomas Adès (pno), ${ }^{1}$ Arditti Quartet, ${ }^{2}$ members of the Belcea Quartet, ${ }^{2}$ Corin Long (db). EMI 724355766427.

With his Piano Quintet, premièred at the 2001 Melbourne Festival, Thomas Adès - not for the first time - courted the mild sort of controversy that has the habit of baffling, if not infuriating, certain sections of the musical community. Exhibit A in this particular case is Adès's decision to cast the Quintet in sonata form, complete with a repeat of the exposition and (damningly) the use of first- and second-time bars. The conclusion to be drawn, we hear, is that this is music about music, an exercise in stylistic commentary to be filed alongside equally clever but curiously unfulfilling works such as Sonata da Caccia, Adès's 1993 tribute to Debussy and Couperin.

For those who have not had the opportunity to test this judgement with their own ears, the release of this recording - which has sat in the EMI vaults for three years - is most welcome. As with the previous discs of Adès's music on the EMI label, the performance (by the composer with the Arditti quartet) is scintillating: it stands as a powerful advocate of this remarkable score, with its fiendish rhythmic subtleties. (The companion piece on the disc, Schubert's Trout Quintet, is performed with similar verve by Adès and members of the Belcea Quartet.)

Listening to Adès's Quintet, it is clear that this is not music about music, per se; rather, sonata form is used as a vehicle to articulate the composer's ingenious, but always expressive, manipulations of time. The opening theme presented by solo first violin - an ascending scalic fragment in a chromatically enriched C major - is almost immediately subject to temporal distortion, being stretched and compressed as the phrasing demands. This transforms into passagework, under which the piano enters with the same theme, now in B major and in the ratio $5: 4$ against the first violin. And so it goes on. By frequently requiring the performers to feel the pulse in ever-changing and often irregular subdivisions of the crotchet, Adès gives the music an elastic, improvisatory feel. Nevertheless, rhythmic precision is paramount, for lines frequently converge, articulating certain points of 
arrival, only to shift out of temporal focus once again.

As one might expect, the development serves to intensify the temporal processes of the exposition, touching on the two logical extremes that these processes imply. At first the individual lines reach a state of maximum dislocation, a somewhat raucous - if unlovely - climax that dramatically fades into a series of chords played in rhythmic unison. As with so much of the exposition, the actual rhythm of these chords is irregular, and though terrifyingly complex on the page, the aural effect is one of continual, if gentle, ebb and flow, rather like breathing.

To repeat, in the recapitulation, the localized warping of time that characterized the exposition, would seem forced after the development. Thus the floating temporalities of the exposition are re-imagined, positioned within a lengthy accelerando which sweeps all in its path. Where the exposition is expansive, the recapitulation is compressed: thus, although it accounts for less than three minutes of a work lasting nearly twenty, the accumulation of energy serves to imbue it with a weight and significance sufficient to balance the preceding material. The use of sonata form is thus no mere crutch or affectation: it is central to the organization of the unfolding temporal drama. Adès's music, at its most vital, forces us to reconsider those musical objects long considered extraneous to contemporary concerns, and in this respect, the Piano Quintet is no different.

Edward Venn

Eli Zion - from St Petersburg to Jerusalem: Music from the 'New Jewish School'. David Geringas (vlc), Jascha Nemtsov (pno). SWR and Hännsler-Classic CD 93.122.

This CD is the fifth in a series devoted to the "New Jewish School', impressively performed by the scholar-pianist Jascha Nemtsov with the outstanding Lithuanian cellist David Geringas. Nemtsov, organiser of a recent conference in Potsdam (reviewed in Tempo Vol.58, no.230) and author of two books on the subject, is an ideal candidate to provide a fascinating window into the group of composers and performers who championed Jewish music in the first half of the 20th century. From its roots in St Petersburg in 1908, the 'Society for Jewish Folk Music' spread to Moscow, led there by Joel Engel, 'father' of Israeli music; thence to Berlin and Vienna, across Europe and to Palestine. Through folklore research, composition, concerts and publications, it laid the foundations for Jewish music of later generations as shown by the works represented on this CD. Rare items include Joseph Achron's Fragment mystique, the fiery Chassidic Dance by Lazar Saminsky (founder of the American Composer's Guild), and the intense Rhapsodie (Récitatif et Danse Hassidique) by Solomon Rosowksy, prolific synagogue music composer. All three moved from Russia to Palestine in the 1920s and 30s before settling in America.

Particularly fascinating are the works of the less familiar Leo Zeitlin (1884-1930), a colleague of Achron, and of Sinowi Feldman (1893-1942), who became a composer of Russian military marches. Zeitlin's luscious, cantorial-style Eli Zion, which gives the $\mathrm{CD}$ its title, was, according to the erudite sleeve notes, one of the most frequently played pieces of the 'New Jewish School' between 1910-1930. It receives here its world première recording, alongside Feldman's impassioned Poem and Rosowsky's Rhapsodie, all three of which seem to have French echoes in their harmonies. Meanwhile there is a far more modernist orientalized texture to the eloquent Israeli Suite, four contrasing dances by Joachim Stutschewsky, the notable Russian cellist, who was a member of the Viennese Kolisch Quartet, and who settled in Israel. Bloch's famous Méditation Hebraiqque is also included, somewhat controversially: though he stands apart from the Russian composers he may have been influenced by them, Nemtsov argues, in his early Jewish works, before settling in the USA. Musically engaging, as well as significant historically, this beautifully performed CD highlights the artistic potency of a consciously-conceived Jewish art music style based on traditional sources; it thus makes an important contribution to our appreciation of Jewish and Israeli music as well as the development of national schools in the 20th century. 